\title{
ON THE VALENCE OF ANTIBODIES
}

\author{
By KIYoshI OIKAWA \\ National Institute of Health of Japan, Tokyo \\ (Received for publication, May 2,1950 )
}

In the studies on the mechanism of immunity reactions, Umezawa (1) criticized the comparative merits of two-stage theory of Bordet and the lattice theory proposed by Marrack (2). His results were reasonably explained by the latter.

It is an essential assumption of the lattice theory that antibodies and antigens must be multivalent to each other, in order to form a framework structure of antigen-antibody complex. One molecule of antibody must possess at least two sites with which it combines antigens. Meanwhile the two-stage theory can explain the formation of precipitates if the antibody is monovalent. The multivalency of antigens was asscertained experimentally by many authors (3-5). While the problem of the valency of antibody, though it holds sway over the justification of these two theories, had not been decided directly by the time when I undertook the following experiment (1946). The multivalency of antibody was ascertained by my experiment as follows.

When a rabbit is immunized with horse serum globulin $(G)$ coupled with a simple substance of known chemical structure (a) as a determinant group, it is always observed that heterogenous antibodies are produced in its serum. If antibodies are bivalent, they may be grouped into next three types, if such are actually produced.

(i) Both combining sites are specific to (a).

(ii) Both combining sites are specific to $(\mathrm{G})$.

(iii) One site of combination is specific to (a), while the other is specific to $(G)$.

If, on the contrary, antibodies are monovalent, their single combining site will be

$\left(i^{\prime}\right)$ specific to (a), or

(ii') specific to $(\mathrm{G})$; or

(iii') specific to the linkage of (a) and $(G)$.

Suppose simple hapten (A) containing the above group (a), is added to the antiserum. Then in the former case, it should bind with antibodies of the types (i) and (iii), while in the latter case with ( $\left.i^{\prime}\right)$ and ( iii $\left.^{\prime}\right)$, but no precipitate will be formed in both cases.

Then add horse serum globulin to the mixture. If antibodies are bivalent, antibodies of type (ii) are of course precipitated with globulin molecules. But also those of type (iii), only one combining site of which binds with (A), will be taken up into the framework of antigen-antibody complexes with the remaining site, and hence the formed precipitates will contain the hapten (A). Meanwhile if antibodies are monovalen, those of type (iii'), not to speak of those of type ( $\left.i^{\prime}\right)$, can not bind with (G), on account of the spacial expulsion of previously bound hapten (A). Therefore precipitates will consist of (G) and (ii') alone, and substance (A) will not be found in them, except those adsorbed on them non-specifically. 
Thus. when a dye or an easily detectable substance is employed as hapten (A), the valency of antibody can be decided clearly from the colour or analysis of the precipitates. Upon this basis, I made the following experiment. Antibodies were found to possess at least two combining sites and form framework structured precipitates with antigens.

\section{Materials}

\section{(I) Antigens.}

Horse serum globulin was prepared by fractionation with ammonium sulfate in the ustual way. Atoxylazo-horse serum globulin was prepared according to the description of Haurowitz (6). Namely $50 \mathrm{cc}$ of $6 \%$ horse serum globulin solution was added with the same volume of $\mathrm{N}-\mathrm{Na}_{2} \mathrm{CO}_{3}$ and then $2.5 \mathrm{cc}$ of atoxylazo solution was added drop by drop. During this process the mixture was cooled to $0^{\circ} \mathrm{C}$. After 30 minutes, they were neutralized with $\mathrm{N}-\mathrm{HCl}$ and dialysed against streaming water.

Iodinated horse serum globulin was prepared according to Wormall (7).

(II) Antisera.

Two rabbits were immunized with atoxylazo-globulin and iodinated globulin respectively in the usual way, and the pooled sera were inactivated at $56^{\circ} \mathrm{C}$ for 30 minutes.

(III) Haptenic substances. .

Atoxylazo-tyrosine was prepared according to Pauli (8). Diiodtyrosine was prepared according to Bauer and Strauss (9), and purified by dissolving it with $\mathrm{Na}_{2} \mathrm{CO}_{3}$ solution and reprecipitating with acetic acid.

Each $5 \mathrm{mg}$ of both substances was dissolved in $0.5 \mathrm{cc}$ of $\mathrm{N} / 10 \mathrm{NaOH}$ and diluted with physiological saline to the final volume of $5 \mathrm{cc}$.

\section{Experimental Methods and Results}

(I) Atoxylazo-tyrosine as hapten.

Atoxylazo-tyrosine solution $0,5 \mathrm{cc}$, was added to $2 \mathrm{cc}$ of antiazo rabbit serum, and after the mixture was incubated at $37^{\circ} \mathrm{C}$ for 30 minutes, it was centrifuged but no precipitate was formed.

Then $0.1 \mathrm{cc}$ of $5 \%$ horse serum globulin was added and again the mixture was incubated at $37^{\circ} \mathrm{C}$ for 30 minutes. Next, it was frozen, melted and centrifuged. The precipitates thus obtained were brown colored. As a control experiment, anti-iodserum was used instead of antiazo-serum and treated in the same way. In this case the precipitates were only slightly colored. The definite difference of the color of precipitates suggested that in the former case haptenic substance was bound with antibodies by specific binding and precipitated with antigen-antibody complexes; while in the latter case, the faint color was due to non-specific adsorption of haptenic substance by antigen-antibody complexes. The supernatant fluids of the above experiments were repeatedly absorbed with $0.1 \mathrm{cc}$ of globulin solution.

The color of precipitates showed the same difference in every case. However when the precipitates were washed with physiological saline by centrifugation, their color decreased in every washing. Hence the binding force of hapten and antibody seemed 
to be weaker than that of antigen and antibody.

(II) Diiodtyrosine as hapten.

One-half cc of diiodtyrosine solution was added to $2 \mathrm{cc}$ of anti-iod-serum and after the mixture was incubated at $37^{\circ} \mathrm{C}$ for 30 minutes, it was centrifuged, but no precipitate was formed. Then $0.1 \mathrm{cc}$ of $5 \%$ horse serum globulin was added and again the mixture" was incubated at $37^{\circ} \mathrm{C}$ for 30 minutes. Next, it was frozen, melted and the precipitates were centrifuged off. The supernant fluid was again added with $0.1 \mathrm{cc}$ of horse serum globulin solution, and treated as before. This procedure was repeated until no precipitate was formed by adding globulin solution. In this time, antiazo serum was used instead of anti-iod serum as a control.

The collected precipitates were washed by centrifugation with $1 \mathrm{cc}$ portions of physiological saline, absolute alcohol and ether and evapolated to dryness. Iod-contents of weighed samples were measured by Perkin's method modified by Haurowitz and Kraus (10). The amount of precipitate from anti-iod serum was $1.2 \mathrm{mg}$ and its iod-content was $48 \mathrm{mcg}$, while in the case of anti-azo serum those figures were $0.9 \mathrm{mg}$ and $2 \mathrm{mcg}$ respectively. Thus in this experiment, too, haptenic substance was specifically bound by antigenantibody complexes.

\section{Discussion}

Our experimental results as described above are just those predicted by the lattice theory. Moreover the existence of antibodies, one combining site of which is specific to one group, and the other specific to another, is ascertained. After the last war, we had come to be able to read American papers, and found in Pauling's articles on the serological behavior of simple substaeces $(11,12)$, another proof of the bivalency of antibodies. He used a bihaptenic substance (RX) and two different antisera anti-R and anti-X serum and found that this $\mathrm{RX}$ substance did not give a precipitate with either anti-R serum or anti-X serum alone, but did give precipitates with a mixture of these two antisera. This result also can be explained reasonably from the lattice theory.

But there are several authors who insist upon the monovalency of antibodies. However, on detailed examination of their articles, we can find the theoretical failures. of their conclusions, or their results can be explained also from the standpoint of lattice theory.

For example, we shall discuss Haurawitz's paper (13). He absorbed fractionally an antiserum against atoxylazo-iod sheep serum globulin with atoxylazo-ovalbumin, iodovalbmin, atoxylazo-iod-ovalbumin, and atoxylazo-iod sheep serum globulin successively. The amounts of precipitates formed in successive absorption are indicated in the following table. 
Table 1. Fractional precipitation of antiserum against atoxylazo-iod sheep serum globulin with various test antigens.

Experiment No. I

Amount of precipitate

Atoxylazo-ovalbumin

Iod-ovalbumin

Atoxylazo-iod-ovalbumin

Atoxylazo-iod sheep globulin
$1.515 \mathrm{mg}$

1.148

trace

5.818
Amount of antigen in the precipitate

$0.32 \mathrm{mg}$

0.38

1.57

\section{Total}

Amount of antibody

8.481

2.27

$6.23 \mathrm{mg}$

Experiment No. II

Iod-ovalbumin

Atoxylazo-ovalbumin

Atoxylazo-iod-ovalbumin

$1.484 \mathrm{mg}$

1.386

$0.44 \mathrm{mg}$

Atoxylazo-iod sheep globulin

tracee

0.27

6.025

1.58

$\begin{array}{rll}\text { Total } & 8.89 & 2.29 \\ \text { Amount of antibody } & 6.60 \mathrm{mg} & \end{array}$

From this result it is suggested that this antiserum containes besides antibodies against homologous antigen, anti-azo and anti-iod antibodies: the former is precipitated with atoxylazo-ovalbumin, and the latter with iod-ovalbumin. But successive addition of atoxylazo iod-ovalbumin gives no precipitate more. Hence he concluded that antiserum against complex antigen with two determinant groups $\mathrm{A}$ and $\mathrm{B}$, contains antibodies of type anti-A and anti-B, but no antibody of type- $A B$, which is expected to exist if antibody is bivalent. However, this conclusion is mistaken, because if antibody of type anti- $\mathrm{AB}$ is contained, it is absorbed when antigen $\mathrm{A}$ or $\mathrm{B}$ is added, and has been completely consumed by the time when antigen $A B$ is added, therefore the failure of antigen $\mathrm{AB}$ to form precipitates with this absorbed antiserum can not deny the existence of antibodies of the type anti-AB. Moreovers, the indicated figures show that the amount of precipilate formed in the first absorption is always greater than the second, which suggests that anti- $\mathrm{AB}$ antibodies are absorbed with antigen $\mathrm{A}$ or $\mathrm{B}$ added in the first time. Hence this experiment is explained rather fairly from our viewpoint.

Boyd, who had once supported the monovalent theory, changed his opinion (14), and his later research has been turned to the artificial deformation of bivalent antibody into monovalent one $(15,16$, see also 17,18$)$. At present inhibiting antibody is thought to be monovalent, i. e. it can combine with antigen, but cannot be precipitated with it, and inhibits the precipitation of antigen with bivalent antibody (19-22).

I am indebted to Dr. Umezawa, Chief of my division, for his kind suggestions and advice throughout this investigation.

\section{SUMMARY}

(I) Atoxylazo-tyrosine was added to antiserum against atoxylazo horse serum globulin, and then the mixture was added with horse serum globulin. The formed 
precipitate contained atoxylazotyrosine.

(II) Diiodtyrosine was added to antiserum against iodinated horse serum globulin, and then the mixture was added with horse serum globulin. The formed precipitate contained diiodtyrosine.

(III) These results are exactly those predicated by the lattice theory, and prove the multivalency of antibody.

\section{REFERENCES}

1) Umezawa, H.: Studies on the mechanism of the agglutination. I. On the lattice theory. Jap. Med. J., 1, 51, 1948.

2) Marrack, R. J.: The chemistry of antigens and antibodies, Medical Research council, Special Report Series, 230, p. 149, 1938.

3) Marrack, R. J.: ibid. p. 161, 1938.

4) Pauling, L. : A theory of the structure and process of formation of antibodies, J. Amer. Chem. Soc., 62, 2643, 1940.

5) Pauling, L., Pressman, D., Campbell, D. H., Ikeda, C. and Ikawa, M.: The serological properties of simple substances. I. Precipitation reactions between antibodies and substances containing two or more haptenic groups. J. Amer. Chem. Soc., 64, 2994, 1942.

6) Haurowitz, F., Kraus, F. and Marx, F.: Ueber die Bindung zwischen Antigen und präzipitierenden Antikörper. Z. physiol. Chem. 245, 23, 1936.

7) Wormall, A.: The immunological specificity of chemically altered proteins: Halogenated and nitrated protein. J. exp. Med., 51, 295, 1930.

8) Pauli, K.: Zur Kenntnis der Diazoreaktion der Eiweisses. Z. physiol. Chem., 94, 284, 1915.

9) Bauer, H. and Strauss, E.: Beiträge zur Kenntnis substituierter Proteine: Nitrierung und Jodierung des Globins. Biochem. Z. 211, 163, 1929.

10) Haurowitz, F. and Kraus, F.: Die Verteilung chemisch markierter Antigene im Organismus normaler und sensitierter Tiere. Z. physiol. Chem., 239. 76, 1936.

11) Pauling, L., Pressman, D. and Ikeda, C.: The serological properties of simple substances. III The composition of precitates of antibodies and polyhaptenic simple substances: The valence of antibodies. J. Amer. Chem. Soc., 64, 3010, 1342.

12) Pauling, L., Pressman, D. and Campbell, D. H.: The serological.properties of simple substances. VI The precipitation of a mixture of two specific antisera by a dihaptenic substance containing the two corresponding haptanic groups: Evidence for the framework theory of serological precipitation. J. Amer. Chem. Soc., 66, 330, 1944.

13) Haurowitz, F.: Quantitative Untersuchungen über Antigene, Antikörper und Komplement. Schweiz. Med. Wochschr., 73, 264, 1943.

14) Abramscin, H. A., Boyd, W. C., Hooker, S. B., Porter, P. M. and Purnell, M. A.: The specificity of the second stage of bacterial agglutination and hemagglutination. J. Bact., 50, 15, 1945.

15) Boyd, W. C. : Effect of photo-oxidation on isohemagglutinating antibodies. J. exp. Med., 8.3, 221, 1946.

16) Boyd, W. C.: The effect of high pressures on hemagglutinating antibodies. J. exp. Med. 83, 401, 1946.

17) Tyler, A.: Conversion of agglutinins and precipitins into univalent antibodies by the photodynamic irradiation of rabbit antisera vs pneumococci, sheep-red-cells and sea-urchin sperm. J. Immunol., 51, 157, 1945.

18) Wright, G. G.: Studies on the denaturation of antibody. II. The effect of protein concentration on the rate of denaturation of diphtheria antitoxin by urea. J. exp. Med., 81, 647, 1945.

19) Heidelberger, M., Treffers, H. P. and Mayer, M. : A quantitative theory of the precipitin reaction. 
VII The egg albumin-antibody reaction in antisera from rabbit and horse. J. exp. Med., 71, 271, 1940.

20) Pappenheimer, A. M. Jr.: Anti-egg antibody in the horse. J. exp. Med. 71, 263, 1940.

21) Wiener, A. S.: A new tes: (blocking test) for Rh sensitization. Proc. Soc. Exp. Biol. Med., 56, $173,1944$.

22) Levine, P. and Gilmere, E. L.: The first stage of antigen-antibody reaction in infectious mononucleosis. Science, 101, 411, 1945. 